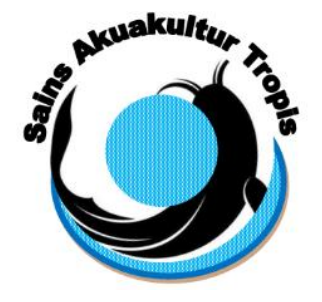

\author{
Jurnal Sains Akuakultur Tropis \\ Departemen Akuakultur \\ Fakultas Perikanan dan Ilmu Kelautan - Universitas Diponegoro \\ JI. Prof. Soedarto, SH, Tembalang, Semarang 50275 \\ Telp. (024) 7474698, Fax.: (024) 7474698 \\ Email: sainsakuakulturtropis@gmail.com, sainsakuakulturtropis@undip.ac.id
}

\title{
PENGARUH PENGGUNAN FERMENTASI TEPUNG KULIT BUAH KAKAO (Theobroma cacao L.) DALAM PAKAN TERHADAP EFISIENSI PEMANFAATAN PAKAN DAN PERTUMBUHAN IKAN MAS( Cyprinus carpio)
}

\author{
The Effect of Dietary Fermented Cacao Pod Husk Flour on the Feed Efficiency Utilization and Growth of Carp \\ (Cyprinus $\underline{\text { carpio) }}$.
}

\author{
Seravina, Subandiyono*, Agung Sudaryono \\ Departemen Akuakultur, \\ Fakultas Perikanan dan Ilmu Kelautan, \\ J1. Prof. Soedarto, SH, Tembalang, Semarang, Jawa Tengah -50275, Telp/Fax. +62247474698 \\ * Corresponding author: s_subandiyono@yahoo.com
}

\begin{abstract}
ABSTRAK
Kulit buah kakao (Theobroma cacao L.) merupakan limbah atau hasil samping agroindustri produksi buah kakao. Kulit buah kakao mengandung protein 9,15\%, lemak 1,96\%, serat kasar 25,64\%, abu 10,39\%, dan bahan ekstrak tanpa nitrogen (BETN) 52,86\%. Kandungan serat kasar yang tinggi pada kulit buah kakao sulit dicerna oleh ikan. Upaya yang dilakukan untuk mengatasi masalah tersebut adalah melalui proses fermentasi. Penelitian ini bertujuan untuk mengkaji penggunaan fermentasi tepung kulit buah kakao (T. cacao L.) dalam pakan terhadap efisiensi pemanfaatan pakan, dan pertumbuhan ikan mas (Cyprinus carpio). Ikan uji yang digunakan adalah ikan mas (C. carpio) dengan bobot individu rata-rata 6,54 \pm 0,07 g/ekor. Pakan diberikan pada pukul 08.00 dan 16.00 secara at satiation. Ikan uji dipelihara selama 42 hari dengan padat tebar 1 ekor/ $2 \mathrm{~L}$. Penelitian ini dilakukan dengan metode eksperimental menggunakan rancangan acak lengkap (RAL) dengan 4 perlakuan dan 3 kali ulangan. Perlakuan penggunaan fermentasi tepung kulit buah kakao A, B, C dan D dengan konsentrasi masingmasing 0\%, 10\%, 20\% dan 30\%. Data yang diamati meliputi total konsumsi pakan (TKP), efisiensi pemanfaatan pakan (EPP), protein efisiensi rasio (PER), pertambahan bobot mutlak (G), laju pertumbuhan spesifik (SGR), dan kelulushidupan (SR). Hasil penelitian menunjukkan bahwa fermentasi tepung kulit buah kakao memberikan pengaruh nyata $(\mathrm{P}<0,05)$ terhadap TKP, EPP, PER, G, SGR serta SR.Perlakuan C $(20 \%)$ memberikan nilai pada TKP sebesar190.1 $\pm 2.98 \mathrm{~g}$, EPP sebesar88.19 $\pm 8.09 \%$, PER sebesar 2.66 $\pm 0.24 \%$, G sebesar 7,26 $\pm 0,11$, SGR sebesar

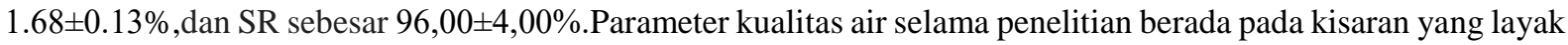
untuk kehidupan ikan mas.Hasil penelitian menyimpulkan bahwa dosis fermentasi tepung kulit buah kakaodalam pakan menghasilkan efisiensi pemanfaatan pakan dan pertumbuhan ikan mas terbaik adalah perlakuan C (20\%).
\end{abstract}

Kata Kunci: fermentasi, kulit kakao, pakan, pertumbuhan, ikan mas

\section{ABSTRACT}

Cacao pod husk (Theobroma cacao L.) is waste or by-products of agro-industry that was produced from cacaoplants. The nutritional content of cacao pod husk consisted of 9,15\% protein, 1,96 \% lipid, 25,64 \% crude fiber, 10,39\% ash, and 52,86\% nitrogen-free extract (NFE). Crude fiber from cacao pod husk was difficult to be digested by fish. The solution for that constraint was by applying fermentation proccess. This experiment was aimed to observe the influence of cacao pod huskflour which has been fermented first before added into the practical diets, on the feed efficiency and growth of carp(Cyprinus carpio). The trial fish used were carp (C. carpio) with an initial average body weight of 6,54 $\pm 0,07 \mathrm{~g} / \mathrm{fish}$. Feeding frequency applied was twice a day, i.e. at 08.00 a.m and 16.00 p.m. and by appliying an at satiation method. The fishes were cultured for 42 days with the stocking density of $1 \mathrm{fish} / 2 \mathrm{~L}$. The experimental method used was completely randomize design (RCD) with 4 treatments and 3 replicates. The treatment of $A, B, C$, and $D$ were the trial diets with the concentration of cacao pod husk flour of 0, 10, 20, and 30\%, respectively. The data measured were feed consumption, feed efficiency (FE), protein efficiency ratio (PER), growth $(G)$, spesific growth rate $(S G R)$, and survival rate $(S R)$. The data showed that the 
use offermented cacao pod husk flourin the diets resulted significant by effects $(P<0,05)$ on the feed consumption, FE, PER,G, SGR, and SR. Treatment Cresulted on the values offeed consumption i.e. 190.1 $2.98 \mathrm{~g}$, FE i.e.

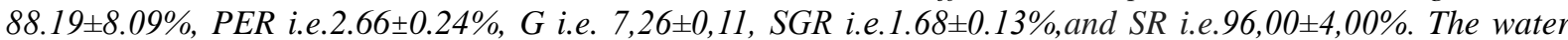
quality parameters during this observe were varied between suitable range for fish life.It was concludedthat the diet containing $20 \%$ of fermented cacao pod husk flour resulted on better feed efficency and growth of the carp.

Keywords: fermentation, cacao pod husk, feed, growth, carp

Article Received: 18-12-2018; Accepted: 12-01-2019

\section{PENDAHULUAN}

Ikan mas (Cyprinus carpio) merupakan salah satu komoditas perikanan air tawar yang mempunyai nilai ekonomis tinggi dan telah banyak dikembangkan di berbagai daerah. Selain itu, ikan mas mempunyai daging yang enak, harga cukup tinggi serta permintaan pasar yang selalu meningkat, cepat tumbuh dan mudah dikembangbiakkan. Menurut Patriono et al. (2009), ikan mas memiliki kandungan asam lemak omega 3 sehingga dapat mengurangi kolesterol dalam darah dan memiliki kandungan protein yang tinggi. Usaha budidaya ikan mas sangat dipengaruhi oleh ketersediaan pakan yang cukup kualitas maupun kuantitasnya. Syarat pakan yang baik adalah memenuhi kandungan gizi yang cukup untuk kebutuhan ikan.

Kegiatan budidaya ikan sangat dipengaruhi oleh ketersediaan pakan yang cukup dalam jumlah dan kualitasnya untuk mendukung kualitas yang maksimal.Menurut Putri et al. (2012), pakan merupakan faktor penentu pertumbuhan dan merupakan biaya terbesar dalam produksi (60-70\%). Saat ini bahan baku utama dalam pembuatan pakan buatan adalah tepung ikan dan tepung kedelai karena mempunyai kandungan protein yang tinggi, namun penyediaannya masih sulit dan harganya relatif mahal.

Kulit kakao dapat dijadikan salah satu bahan alternatif yang dapat digunakan sebagai bahan baku pakan ikan. Tetapi kandungan nutrisi pada kulit kakao masih rendah sehingga diperlukan suatu proses untuk meningkatkan nilai nutrisi pada kulit kakao dengan dilakukannya proses fermentasi yang diharapkan dapat meningkatkan kandungan nutrisi serta menurunkan serat kasar pada kulit kakao agar mudah dicerna oleh ikan. Menurut Sukardi et al. (2012), kulit buah kakao perlu difermentasi terlebih dahulu untuk menurunkan kadar lignin yang sulit dicerna oleh ikan serta dapat meningkatkan kandungan protein dari 6-8\%.

Penelitian ini bertujuan untuk mengkaji pengaruh pengaruh penggunaan fermentasi tepung kulit buah kakao ( $T$. cacao L.) dalam pakan terhadap efisiensi pemanfaatan pakan dan pertumbuhan ikan mas ( $C$. carpio)sehingga mendapatkan informasi kebutuhan pakan yang optimal pada ikan mas. Penelitian ini dilaksanakan pada bulan April hingga Juni 2018 di di Balai Benih Ikan Siwarak Ungaran, Semarang, Jawa Tengah.

\section{MATERI DAN METODE} Materi

Ikan uji yang digunakan penelitian ini adalah ikan mas $($ C. carpio $)$ dengan bobot tubuh rata-rata $6,54 \pm 0,07 \mathrm{~g}$ /ekor. Ikan uji yang digunakan berjumlah 300 ekor yang diperoleh dari Ngrajek, Kabupaten Magelang,Jawa Tengah. Wadah yang digunakan dalam penelitian ini adalah akuarium berdimensi ( $\mathrm{p} \times \mathrm{l} \times \mathrm{t}$ ) sebesar $(65 \times 45 \times 42) \mathrm{cm}^{3}$ berkapasitas $120 \mathrm{~L}$ air. Padat tebar untuk wadah pemeliharan dengan volume air $50 \mathrm{~L}$ adalah 25 ekor atau sama dengan 1 ekor/2L.Ikan uji dipelihara di wadah pemeliharaan selama 7 hari dengan tujuan ikan dapat beradaptasi dengan suhu dan lingkungan barunya. Selanjutnya dilakukan penimbangan bobot ikanserta dilihat kelengkapan organ tubuhnya, dan kesehatan secara fisik dengan tujuan untuk mengetahui keseragaman ikan uji.

Pakan uji yang diberikan untuk ikan mas selama penelitian adalah pakan buatan yang mengandung fermentasi tepung kulit buah kakao. Kulit buah kakao yang digunakan pada penelitian ini berasal dari pengusaha biji kakao di Beji, Ungaran, Kabupaten Semarang. Proses pembuatan tepung buah kulit buah kakao dan fermentasinya yaitu dengan mencacah kulit buah kakao dan direndam air selama 12 jam kemudian dikeringkan di bawah sinar matahari lalu dihaluskan. Tepung kulit buah kakao yang sudah halus kemudian ditimbang dan dicampurkan dengan probiotik. Probiotikyang digunakan sebelumnya telah diaktivasi dengan molase. Campuran tepung kulit buah kakao dan probiotik dimasukkan dalam wadah dan ditutup rapat agar udara dari luar tidak masuk dan terjadi proses fermentasi.

\section{Metode}

Penelitian ini dilakukan secara eksperimental, menggunakan rancangan acak lengkap (RAL) dengan 4 perlakuan dan 3 kali ulangan. Perlakuan A adalah pakan buatan dengan 0\% fermentasi tepung kulit buah kakao, perlakuan B adalah pakan buatan dengan $10 \%$ fermentasi tepung kulit buah kakao, perlakuan C adalah pakan buatan dengan $20 \%$ fermentasi tepung kulit buah kakao, dan perlakuan D adalah pakan buatan dengan $30 \%$ fermentasi tepung kulit buah kakao Metode pemberian pakan secara at satiation dengan frekuensi pemberian pakan sebanyak 2 kali sehari yaitu pagi (08.00) dan sore (16.00). Analisa proksimat pakan uji yang digunakan selama 42 hari pengamatan dapat dilihat pada Tabel 1. 
Tabel 1. Komposisi dan Analisis Proksimat Pakan Uji yang Digunakan Selama 42 Hari Pengamatan

\begin{tabular}{|c|c|c|c|c|}
\hline \multirow{2}{*}{ Bahan Penyusun (g/100g) } & \multicolumn{4}{|c|}{ Komposisi Pakan (\%) } \\
\hline & $\mathrm{A}(0 \%)$ & $\mathrm{B}(10 \%)$ & $\mathrm{C}(20 \%)$ & $\mathrm{D}(30 \%)$ \\
\hline Tepung Ikan ${ }^{1)}$ & 47,45 & 47,45 & 47,45 & 47,45 \\
\hline Tepung Kedelai ${ }^{1)}$ & 14,51 & 14,31 & 14,2 & 13,05 \\
\hline Tepung Jagung ${ }^{2)}$ & 16,58 & 11,17 & 6,45 & 0 \\
\hline Tepung Kulit Buah Kakao Fermentasi ${ }^{3)}$ & 0 & 10 & 20 & 30 \\
\hline Tepung Terigu ${ }^{2)}$ & 11,96 & 7,57 & 2,4 & 0 \\
\hline Minyak Ikan²) & 1,45 & 1,37 & 1,31 & 1,23 \\
\hline Minyak jagung 2 ) & 4,55 & 4,63 & 4,69 & 4,77 \\
\hline Vit-min $\operatorname{mix}^{2)}$ & 2 & 2 & 2 & 2 \\
\hline Carboxy Methyl Cellulose $e^{2)}$ & 1 & 1 & 1 & 1 \\
\hline $\mathrm{Cr}_{2} \mathrm{O}_{3}{ }^{4)}$ & 0,5 & 0,5 & 0,5 & 0,5 \\
\hline \multicolumn{5}{|l|}{ Komposisi Proksimat } \\
\hline Protein $(\%)^{5)}$ & 33,02 & 33,11 & 33,16 & 32,93 \\
\hline $\operatorname{BETN}(\%)^{5)}$ & 27,67 & 27,75 & 28,15 & 26,71 \\
\hline Lemak $(\%)^{5)}$ & 11,10 & 11,23 & 11,33 & 10,97 \\
\hline Energi $\left.(\mathrm{kkal})^{6}\right)$ & 274,61 & 276,21 & 278,22 & 270,88 \\
\hline Rasio E/P $\mathrm{P}^{7)}$ & 8,32 & 8,34 & 8,39 & 8,23 \\
\hline
\end{tabular}

Keterangan:

1) Bahan baku pakan diperoleh dari penjual di Rembang

2) Bahan baku pakan diperoleh di toko komersial di Semarang

3) Bahan baku pakan diperoleh dari hasil pembuatan sendiri

4) Bahan diperoleh dari Laboratorium Nutrisi Pakan FPP, UNDIP, Semarang

${ }^{5)}$ Hasil analisis proksimat pakan (Laboratorium Nutrisi Pakan FPP, UNDIP, Semarang)

\section{Pengumpulan data}

Variabel yang diukur meliputi nilai total konsumsi pakan (TKP), efisiensi pemanfaatan pakan (EPP), protein efisiensi rasio (PER), pertambahan bobot mutlak (G),laju pertumbuhan spesifik (SGR), dankelulushidupan (SR).

\section{Total konsumsi pakan}

Nilaitotal konsumsi pakan dihitung dengan menggunakan rumus Setiawati et al. (2008).

Keterangan:

$$
\mathrm{TKP}=\mathrm{F} 1-\mathrm{F} 2
$$

$\begin{array}{ll}\text { TKP } & \text { Total konsumsi pakan }(\mathrm{g}) \\ \mathrm{F} 1 & =\text { Jumlah pakan awal }(\mathrm{g}) \\ \mathrm{F} 2 & =\text { Jumlah pakan akhir }(\mathrm{g})\end{array}$

\section{Efisiensi pemanfaatan pakan}

Nilaiefisiensi pemanfaatan pakandihitung dengan menggunakan rumus Zonneveld et al. (1991).

$$
\mathrm{EPP}=\frac{\mathrm{W}_{\mathrm{t}}-\mathrm{W}_{\mathrm{o}}}{\mathrm{F}} \times 100 \%
$$

Keterangan:

$$
\begin{array}{ll}
\text { EPP } & \text { Efisiensi pemanfaatan pakan }(\%) \\
\mathrm{W}_{\mathrm{t}} & =\text { Bobot total ikan pada akhir penelitian }(\mathrm{g}) \\
\mathrm{W}_{\mathrm{o}} & =\text { Bobot total ikan pada awal penelitian }(\mathrm{g}) \\
\mathrm{F} & =\text { Jumlah pakan yang dikonsumsi selama penelitian }(\mathrm{g})
\end{array}
$$

\section{Protein efisiensi rasio}

Nilai protein efisiensi rasio dihitung dengan menggunakan rumus Zonneveld et al. (1991).

$$
\mathrm{EPP}=\frac{\mathrm{W}_{\mathrm{t}}-\mathrm{W}_{\mathrm{o}}}{\mathrm{Pi}} \times 100 \%
$$

Keterangan:

$$
\begin{array}{ll}
\text { PER } & \text { Protein efisiensi rasio }(\%) \\
\mathrm{W}_{\mathrm{t}} & =\text { Bobot total ikan pada akhir penelitian }(\mathrm{g}) \\
\mathrm{W}_{\mathrm{o}} & =\text { Bobot total ikan pada awal penelitian }(\mathrm{g}) \\
\mathrm{P} & =\text { Berat pakan yang dikonsumsi } \mathrm{x} \% \text { protein pakan }
\end{array}
$$




\section{Pertambahan bobot mutlak}

Nilai pertambahan bobot mutlak dihitung dengan menggunakan rumus Zonneveld et al. (1991).

Keterangan:

$$
\mathrm{G}=\Delta \mathrm{W}=\mathrm{W}_{\mathrm{t}}-\mathrm{W}_{\mathrm{o}}
$$

$\begin{array}{ll}\mathrm{G} & =\text { Pertambahan bobot mutlak }(\mathrm{g}) \\ \mathrm{W}_{\mathrm{t}} & =\text { Bobot ikan pada waktu } \mathrm{t}(\mathrm{g}) \\ \mathrm{W}_{\mathrm{o}} & =\text { Bobot ikan awal }(\mathrm{g})\end{array}$

\section{Laju pertumbuhan spesifik}

Nilai laju pertumbuhan spesifikdihitung dengan menggunakan rumus Zonneveld et al. (1991).

$$
\mathrm{SGR}=\frac{\operatorname{Ln} \mathrm{W}_{\mathrm{t}}-\operatorname{Ln} \mathrm{W}_{\mathrm{o}}}{\mathrm{t}} \times 100 \%
$$

\section{Keterangan:}

SGR = Laju pertumbuhan spesifik (\%bobot/hari)

$L n \mathrm{~W}_{\mathrm{t}} \quad=$ Bobot total ikan pada akhir pemeliharaan $(\mathrm{g})$

$L n \mathrm{~W}_{\mathrm{o}} \quad=$ Bobot total ikan pada awal pemeliharaan $(\mathrm{g})$

$\mathrm{t}=$ Periode pengamatan $(\Delta t)$

\section{Kelulushidupan}

Nilai kelulushidupan dihitung dengan menggunakan rumus Zonneveld et al. (1991).

$$
\mathrm{SR}=\frac{\mathrm{N}_{\mathrm{t}}}{\mathrm{N}_{0}} \times 100 \%
$$

\section{Keterangan:}

$\begin{array}{ll}\mathrm{SR} & =\text { Tingkat kelulushidupanikan (\%) } \\ \mathrm{N}_{\mathrm{t}} & =\text { Jumlah ikan pada akhir penelitian (ekor) } \\ \mathrm{N}_{0} & =\text { Jumlah ikan padaawal penelitian (ekor) }\end{array}$

\section{Kualitas air}

Parameter kualitas air seperti pengukuran suhu dilakukan setiap hari pada pagi dan sore hari dengan menggunakan thermometer. Pengukuran $\mathrm{pH}$ dan $\mathrm{DO}$ dilakukan satu minggu sekali dengan menggunakan $\mathrm{pH}$ meter dan DO meter. Pengukuran amonia dilakukan pada awal dan akhir penelitian pemeliharaan dilakukan di laboratorium Teknik Lingkungan, Universitas Diponegoro.Semua pengukuran kualitas air disampling pada setiap bak pemeliharaan.

\section{Analisis data}

Data yang diperoleh meliputi total konsumsi pakan (TKP), efisiensi pemanfaatan pakan (EPP), protein efisiensi rasio (PER), laju pertumbuhan spesifik (SGR), dan kelulushidupan (SR) terlebih dahulu dilakukan uji normalitas, uji homogenitas, dan uji additivitas guna memastikan bahwa ragam data bersifat normal, homogen, dan aditif. Data kemudian dilakukan uji lebih lanjut yaitu analisis ragam (ANOVA). Analisis data dilakukan dengan menggunakan Microsoft Excel 2010 dan SPSS versi 23.0. Data dianalisis ragam (uji F) pada taraf kepercayaan $95 \%$. Apabila dalam analisis ragam diperoleh beda nyata $(\mathrm{P}<0,05)$, maka dilakukan uji wilayah ganda Duncan untuk mengetahui perbedaan antar perlakuan. Data kualitas air dianalisis secara deskriptif dan dibandingkan dengan nilai kelayakan kualitas air pada budidaya ikan untuk mendukung pertumbuhan ikan nila selama penelitian.

\section{HASIL}

Hasil pengukuran rerata nilai total konsumsi pakan (TKP), efisiensi pemanfaatan pakan (EPP), protein efisiensi rasio (PER), pertambahan bobot mutlak (G), laju pertumbuhan spesifik (SGR), dan kelulushidupan (SR) dapat dilihat pada Tabel 2 . 
Tabel 2.Nilai Rerata (n=3) TKP, EPP, PER, G, SGR, dan SRpada Ikan Mas(C. carpio)selama 42 Hari Pengamatan

\begin{tabular}{ccccc}
\hline \multirow{2}{*}{ Parameter Uji } & \multicolumn{3}{c}{ Perlakuan } \\
\cline { 2 - 4 } TKP (g) & $175.90 \pm 18.61^{\mathrm{a}}$ & $181.70 \pm 0.89^{\mathrm{a}}$ & $190.1 \pm 2.98^{\mathrm{ab}}$ & $201.47 \pm 1.63^{\mathrm{b}}$ \\
EPP (\%) & $52.68 \pm 4.18^{\mathrm{b}}$ & $67.91 \pm 4.93^{\mathrm{c}}$ & $88.19 \pm 8.09^{\mathrm{d}}$ & $32.17 \pm 5.89^{\mathrm{a}}$ \\
PER (\%) & $1.60 \pm 0.13^{\mathrm{b}}$ & $2.05 \pm 0.15^{\mathrm{c}}$ & $2.66 \pm 0.24^{\mathrm{d}}$ & $0.98 \pm 0.18^{\mathrm{a}}$ \\
G (g) & $5,10 \pm 0,11^{\mathrm{b}}$ & $5,94 \pm 0,25^{\mathrm{c}}$ & $7,26 \pm 0,11^{\mathrm{d}}$ & $4,33 \pm 0,03^{\mathrm{a}}$ \\
SGR (\%/hari) & $1.08 \pm 0.14^{\mathrm{b}}$ & $1.33 \pm 0.07^{\mathrm{c}}$ & $1.68 \pm 0.13^{\mathrm{d}}$ & $0.79 \pm 0.12^{\mathrm{a}}$ \\
SR (\%) & $88,00 \pm 4,00^{\mathrm{ab}}$ & $92,00 \pm 4,00^{\mathrm{bc}}$ & $96,00 \pm 4,00^{\mathrm{c}}$ & $84,00 \pm 4,00^{\mathrm{a}}$ \\
\hline
\end{tabular}

Keterangan: Nilai dengan huruf superscript yang berbeda menunjukan hasil yang berbeda nyata $(\mathrm{P}<0,05)$

\section{Efisiensi pemanfaatan pakan}

Berdasarkan uji polinomial orthogonal EPP diperoleh hubungan yang berpola kuadratik $y=-0.178 x^{2}+4.931 x+$ $48.61, \mathrm{R}^{2}=0.760$ dari persamaan tersebut diperoleh dosis fermentasi tepung kulit buah kakao optimal sebesar $13.8 \%$ yang mampu menghasilkan EPP maksimal $82.76 \%$. Nilai $\mathrm{R}^{2}$ menunjukkan bahwa $76 \%$ EPP pakan dipengaruhi oleh penggunaan fermentasi tepung kulit buah kakao dalam pakan buatan, 34\% EPP dipengaruhi oleh faktor lain. Selanjutnya, untuk mengetahui dosis optimum pada efisiensi pemanfaatan pakan dilakukan uji Polinomial Orthogonal. Hasil grafik dari uji Polinomial Orthogonal tersaji pada Gambar 1.

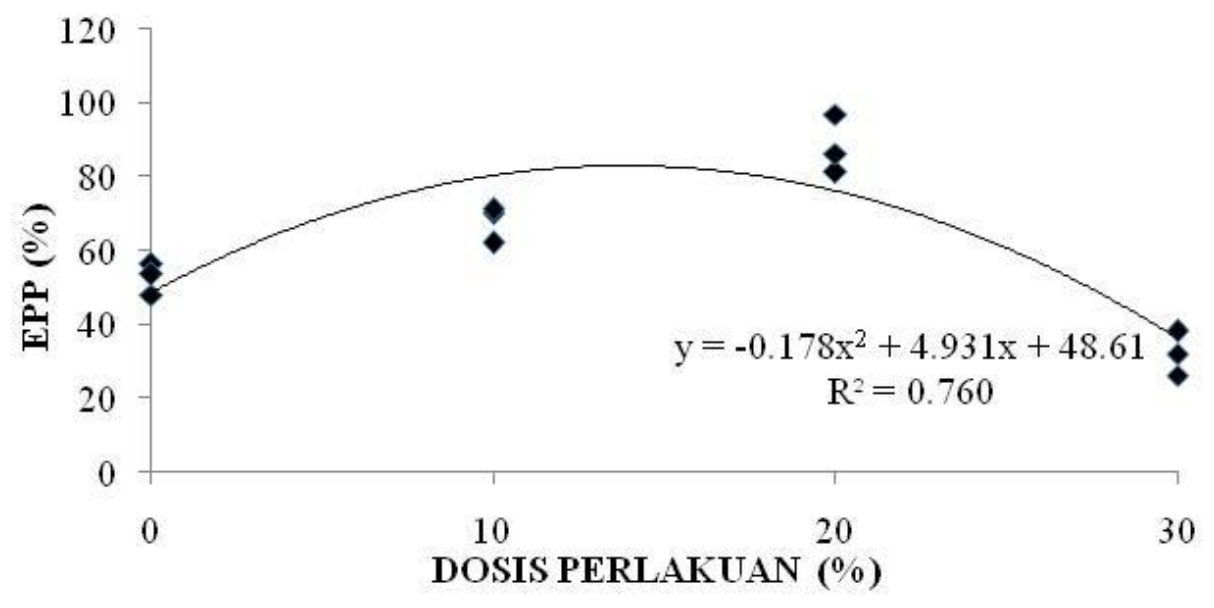

Gambar 1. Grafik Polinomial Ortogonal Efisiensi Pemanfaatan Pakan IkanMas (C. carpio) selama 42 Hari Pengamatan

\section{Protein efisiensi rasio}

Berdasarkan uji polinomial orthogonal PER diperoleh hubungan yang berpola kuadratik $\mathrm{y}=-0.005 \mathrm{x}^{2}$ $+0.147 \mathrm{x}+1.473, \mathrm{R}^{2}=0.760$ dari persamaan tersebut diperoleh dosis fermentasi tepung kulit buah kakao optimal sebesar $14 \%$ yang mampu menghasilkan PER maksimal 2.55\%. Nilai $\mathrm{R}^{2}$ menunjukkan bahwa $76 \%$ PER dipengaruhi oleh penggunaan fermentasi tepung kulit buah kakao dalam pakan buatan, sedangkan 34\% PER dipengaruhi oleh faktor lain. Selanjutnya, untuk mengetahui dosis optimum pada protein efisiensi rasio dilakukan uji Polinomial Orthogonal. Hasil grafik dari uji Polinomial Orthogonal tersaji pada Gambar 2. 


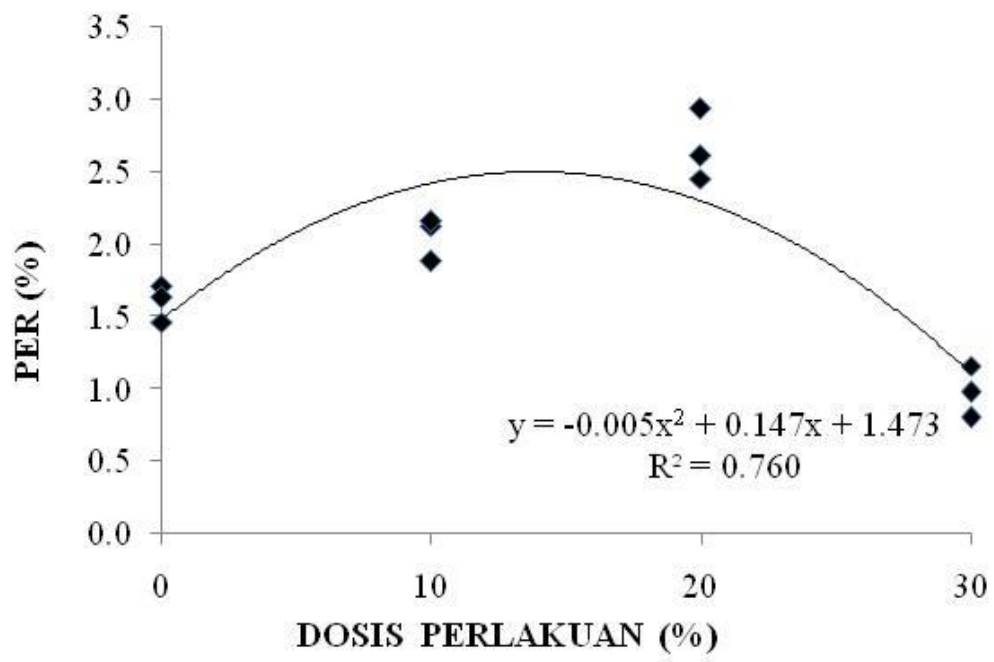

Gambar 2. Grafik Polinomial Ortogonal Protein Efisiensi Rasio Ikan Mas (C. carpio) selama 42 Hari Pengamatan

\section{Pertambahan bobot mutlak}

Berdasarkan uji polinomial orthogonal pertambahan bobot mutlak diperoleh hubungan yang berpola kuadratik y $=-0.009 \mathrm{x}^{2}+0.273 \mathrm{x}+4.864, \mathrm{R}^{2}=0.755$ dari persamaan tersebut diperoleh dosis fermentasi tepung kulit buah kakao optimal sebesar $14.5 \%$ yang mampu menghasilkan pertambahan bobot mutlak maksimal 6.93 g. Nilai $\mathrm{R}^{2}$ menunjukkan bahwa $75.5 \%$ pertambahan bobot mutlak dipengaruhi oleh penggunaan fermentasi tepung kulit buah kakao dalam pakan buatan, sedangkan $24.5 \%$ pertambahan bobot mutlak dipengaruhi oleh faktor lain. Selanjutnya, untuk mengetahui dosis optimum pada pertambahan bobot mutlak dilakukan uji Polinomial Orthogonal. Hasil grafik dari uji Polinomial Orthogonal tersaji pada Gambar 3.

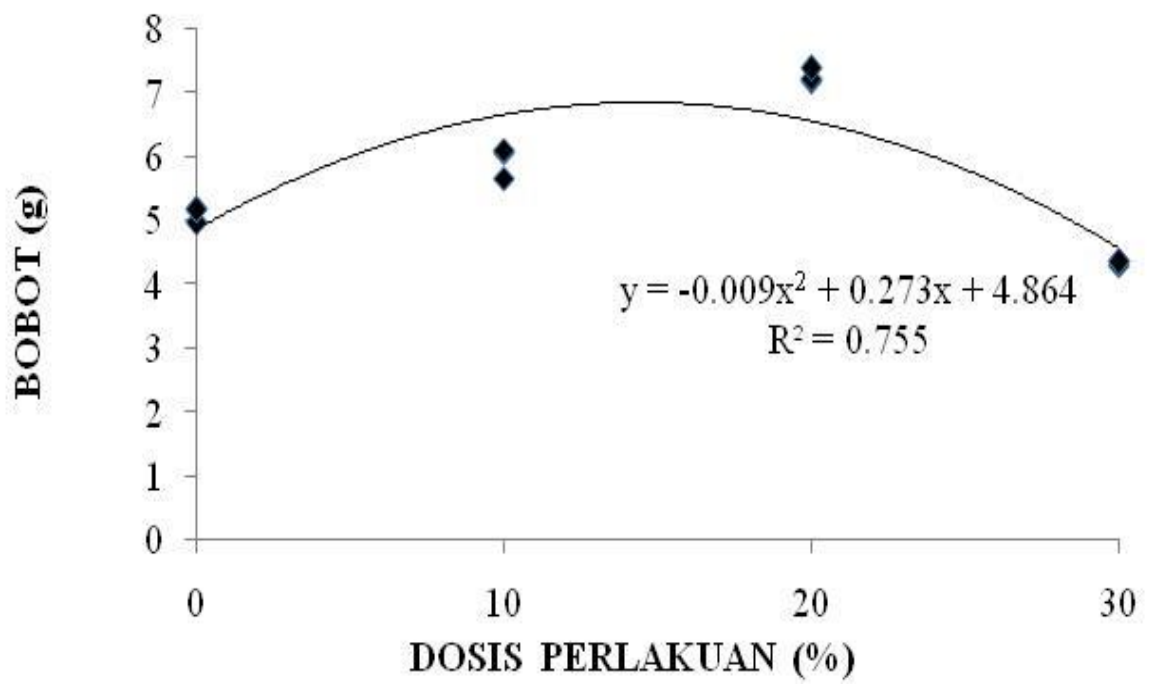

Gambar 3. Grafik Polinomial Ortogonal Pertambahan Bobot Mutlak Ikan Mas (C. carpio) selama 42 Hari Pengamatan

\section{Laju pertumbuhan spesifik}

Berdasarkanuji polinomial orthogonal SGR diperoleh hubungan yang berpola kuadratik y $=-0.002 \mathrm{x}^{2}+$ $0.080 \mathrm{x}+1.012, \mathrm{R}^{2}=0.729$ dari persamaan tersebut diperoleh dosis fermentasi tepung kulit buah kakao optimal sebesar $14.3 \%$ yang mampu menghasilkan SGR maksimal $1.75 \%$ hari. Nilai R² menunjukkan bahwa $72.9 \%$ SGR dipengaruhi oleh penggunaan fermentasi tepung kulit buah kakao dalam pakan buatan, sedangkan 27.1\% SGR dipengaruhi oleh faktor lain. Selanjutnya, untuk mengetahui dosis optimum pada laju pertumbuhan spesifik dilakukan uji Polinomial Orthogonal. Hasil grafik dari uji Polinomial Orthogonal tersaji pada Gambar 4. 


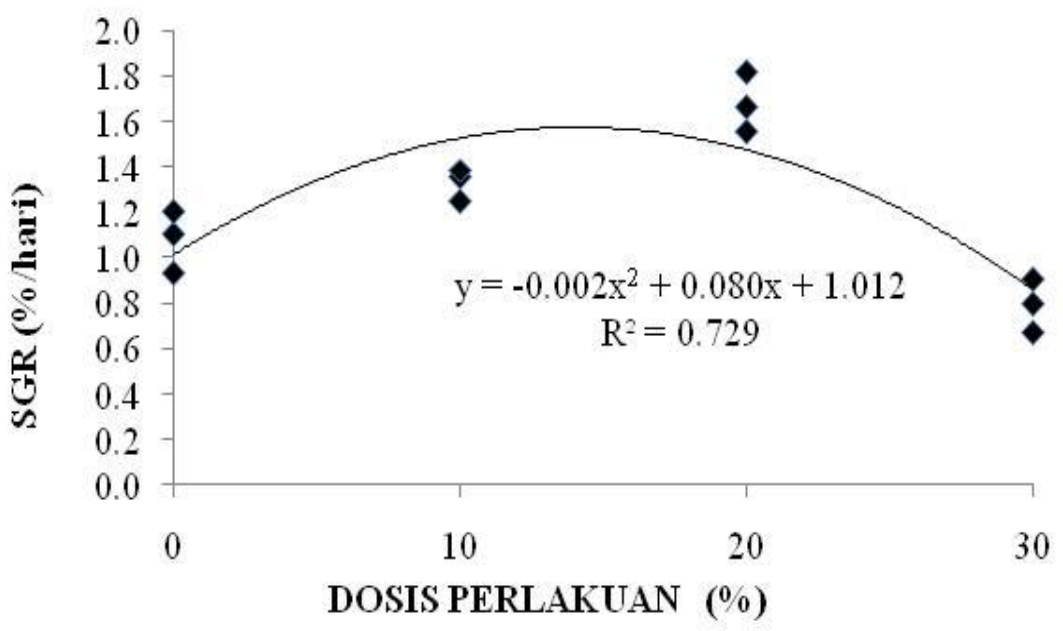

Gambar 4. Grafik Polinomial Ortogonal Laju Pertumbuhan Spesifik Ikan Mas (C. carpio) selama 42 Hari Pengamatan

Hasil analisis ragam menunjukan bahwa perbedaan dosis fermentasi tepung kulit buah pada pakan buatan memberikan pengaruh yang berbeda nyata $(\mathrm{P}<0,05)$ terhadap TKP,EPP, PER, G, SGR dan SRHasil pengukuran kualitas air pada media pemeliharaan ikan mas(C. carpio)selama penelitian tersaji dalam Tabel 3.

Tabel 3.NilaiParameter Kualitas Air Ikan Mas(C. carpio)selama 42Hari Pengamatan

\begin{tabular}{ccccc}
\hline \multirow{2}{*}{ Perlakuan } & \multicolumn{4}{c}{ Kisaran Nilai Parameter Kualitas Air } \\
\cline { 2 - 5 } & Suhu $\left({ }^{0} \mathrm{C}\right)$ & $\mathrm{pH}$ & $\mathrm{DO}(\mathrm{Mg} / \mathrm{L})$ & Amonia \\
\hline A & $25-29$ & 7 & $3,65-4,29$ & $0,0060-0,0119$ \\
B & $25-30$ & 7 & $3,87-4,39$ & $0,0082-0,0087$ \\
$\mathrm{C}$ & $25-30$ & 7 & $3,71-4,41$ & $0,0022-0,0066$ \\
D & $25-30$ & 7 & $3,36-4,68$ & $0,0019-0,0084$ \\
\hline Kelayakan & $24-30^{\mathrm{a}}$ & $6,5-8^{\mathrm{b}}$ & $\geq 3^{\mathrm{b}}$ & $<1 \mathrm{mg} / \mathrm{L}^{\mathrm{c}}$ \\
\hline
\end{tabular}

Keterangan: a) SNI (2009); b)Zonneveld (1991); c) Kordi dan Tancung (2007)

Hasil pengukuran parameter kualitas air selama penelitian menunjukkan bahwa nilai parameter kualitas air selama penelitian tersebut masih berada dalam kondisi layak untuk dijadikan media budidaya ikan mas $(C$. carpio). Hal ini didasarkan dari pustaka tentang kondisi kualitas air yang optimal untukikan mas(C. carpio).

\section{PEMBAHASAN}

\section{Total Konsumsi Pakan}

Hasil analisis ragam menunjukkan bahwa perbedaan dosis penambahan fermentasi tepung kulit buah kakao berpengaruh nyata $(\mathrm{P}<0,05)$ terhadap nilai total konsumi pakan ikan mas $(C$. carpio $)$. Total konsumsi pakan

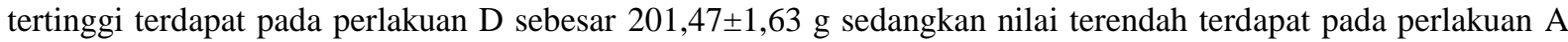

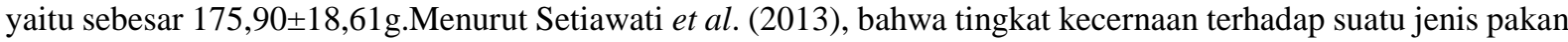
bergantung pada kualitas pakan, komposisi bahan pakan, kandungan gizi pakan, jenis serta aktivitas enzim pencernaan, ukuran dan umur ikan, serta sifat fisik dan kimia perairan.

Tingkat konsumsi pakan yang tinggi dapat memengaruhi adanya laju pertumbuhan ikan mas tersebut. Hal ini disebabkan karena pakan yang dibuat pada dosis tersebut memiliki tekstur pakan yang disukai oleh ikan. Hal tersebut diperkuat oleh Abidin et al. (2015), perbedaan tingkat konsumsi pakan dapat dipengaruhi oleh kandungan dan karakteristik fisik pakan seperti ukuran, bentuk, warna, tekstur, rasa dan bau. Konsumsi pakan akan memberikan pertumbuhan bagi tubuh ikan apabila pakan dapat dicerna dengan baik. Kualitas air pada media pemeliharaan juga sangat berpengaruh terhadap ikan uji, ikan yang sehat akan mampu mengonsumsi pakan yang diberikan. 


\section{Efisensi Pemanfaatan Pakan}

Hasil penelitian menunjukkan bahwa perbedaan dosis fermentasi tepung kulit buah kakao ke dalam pakan memberikan pengaruh nyata $(\mathrm{P}<0,05)$ terhadap efisiensi pemanfaatan pakan ikan mas (C.carpio). Ikanyang

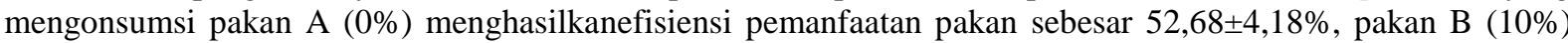

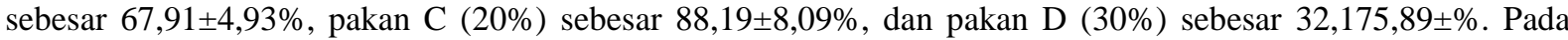
perlakuan Ddosis penambahan fermentasi kulit buah kakao (T. cacao L.)30\%pada pakan sebesar 32,17\% ikan mengalami penurunan efisiensi pakan. Hal ini dikarenakan semakin banyaknya bakteri probiotik maka akan menyebabkan terjadinya akumulasi metabolit dan persaingan dalam penggunaan nutrisi. Banyaknya enzim yang merupakan hasil metabolit akan menyebabkan bakteri tersebut sebagian mati. Hal ini diperkuat oleh Anggraeni dan Abdulgani (2013), daya cerna ikan akan berkurang karena tidak adannya enzim pencernaan yang dihasilkan akibat bakteri tersebut yang mati, sehingga pakan menjadi kurang efisien.

Nilai pemanfaatan pakan yang rendah diduga karena pada perlakuan D (dosis 30\%) mengandung lebih banyak tepung kulit buah kakao dibandingkan dengan perlakuan lainnya. Pada dasarnya kulit buah kakao mengandung serat kasar yang tinggi yang cenderung sulit untuk dicerna oleh ikan. Walaupun telah melalui proses fermentasi, kandungan serat kasar kulit buah kakao hanya berkurang sedikit. Oleh karena itu memungkinkan pakan tersebut sulit dicerna oleh ikan. Menurut penelitian Hemre et al. (2002), pakan yang mengandung serat kasar tinggi dapat mengurangi bobot badan ikan, dan memberikan rasa kenyang karena komposisi karbohidrat kompleks yang dapat mengurangi nafsu makan sehingga mengakibatkan turunnya konsumsi pakan dan menurunkan pertumbuhan ikan.

\section{Protein Efisiensi Rasio}

Hasil penelitian menunjukkan bahwa perbedaan dosis fermentasi tepung kulit buah kakao ke dalam pakan memberikan pengaruh nyata $(\mathrm{P}<0,05)$ terhadap protein efisiensi rasio ikan mas (C.carpio).Nilai protein efisiensi rasio dipengaruhi oleh kemampuan ikan untuk mencerna pakan. Kemampuan ini dipengaruhi oleh beberapa faktor yaitu komposisi pakan, semakin tinggi protein yang dimanfaatkan oleh tubuh maka protein yang dimanfaatkan semakin efisien. Ali et al. (2015), nilai protein efisiensi rasio mengalami penurunan ketika kandungan protein pakannya meningkat pada nilai imbangan energi-protein yang sama.

Perlakuan yang tertinggi pada nilai protein rasio adalah perlakuan $\mathrm{C}$ dengan dosis penambahan fermentasi kulit buah kakao (T. cacao L.)20\%pada pakan sebesar 2,66 $\pm 0,24 \%$. Peneliti menduga meskipun perlakuan $30 \%$ (D) lebih disukai oleh ikan mas(C. carpio) dengan konsumsi protein yang sama, namun kandungan pakan 20\%(C) dapat digunakan secara efisien untuk mengasilkan protein yang dimanfaatkan secara maksimal sehingga menghasilkan presentase bobot protein yang lebih tinggi dibanding dengan perlakuan ikan yang diberi makan 30\% (D). Menurut Hepher (1988), protein dapat dimanfaatkan secara maksimal untuk pertumbuhan karena ikan mampu memanfaatkan karbohidrat lebih baik untuk metabolisme sehingga protein yang ada lebih dapat dimanfaatkan secara maksimal untuk pertumbuhan. Keadaan ini sama menurut Tacon (1987), semakin tinggi protein efisiensi rasio berarti semakin baik kualitas dari pakan tersebut.

\section{Pertambahan Bobot Mutlak}

Hasil penelitian menunjukkan bahwa nilai pertumbuhan bobot mutlakikan mas (C. carpio) berpengaruh (P $<0,05)$ pada perbedaan dosis penambahan fermentasi tepung kulit buah kakao. Setelah dilakukan uji Duncan perlakuan yang tertinggi pada pertumbuhan bobot mutlak $(\mathrm{P}<0,05)$ adalah perlakuan $\mathrm{C}$ dengan dosis penambahan fermentasi kulit buah kakao 20\%pada pakan sebesar 7,26 $\pm 0,114 \%$. Nilai pertumbuhan bobot mutlak yang terendah pada perlakuan D dengan dosis penambahan fermentasi kulit buah kakao 30\%pada pakan sebesar $33 \pm 0,03 \%$. Menurut Hertrampf dan Pascual (2000), Kendala utama dalam pemanfaatan bahan nabati termasuk kulit buah kakao sebagai bahan baku pakan ikan adalah kandungan protein yang rendah, serat yang tinggi, lemak yang rendah.

Pertumbuhan ikan yang relatif lambat disebabkan karena kandungan energi pakan khususnya yang berasal dari karbohidrat dan lemak tidak cukup untuk proses metabolisme. Akibatnya protein digunakan untuk proses tersebut, sehingga protein dalam pakan tidak mencukupi bagi ikan untuk proses pertumbuhan.Menurut Dani et al. (2005) bahwa cepat tidaknya pertumbuhan ikan, ditentukan oleh banyaknya protein yang dapat diserap dan dimanfaatkan oleh ikan sebagai zat pembangun.Oleh karena itu, agar ikan dapat tumbuh dengan baik, pakan yang diberikan harus memiliki kandungan energi yang cukup untuk memenuhi kebutuhan energi metabolisme dan memiliki kandungan protein yang cukup tinggi untuk memenuhi kebutuhan pembangunan sel-sel tubuh yang baru.

\section{Laju Pertumbuhan Spesifik}

Laju pertumbuhan spsifik ikan mas $(C$. carpio $)$ berpengaruh $(\mathrm{P}<0,05)$ pada perbedaan dosis penambahan fermentasi tepung kulit buah kakao. Setelah dilakukan uji Duncan perlakuan yang tertinggi pada laju pertumbuhan spesifik $(\mathrm{P}<0,05)$ adalah perlakuan $\mathrm{C}$ dengan dosis penambahan fermentasi kulit buah kakao (T. cacao L.)20\% pada pakan sebesar $1.68 \pm 0.13 \%$. Nilai laju pertumbuhan spesifik yang terendah pada perlakuan D dengan dosis penambahan fermentasi kulit buah kakao (T. cacao L.)30\% pada pakan sebesar 0.79 $\pm 0.12 \%$.Menurut Aggraeni dan Abdulgani (2013), Hasil pengukuran laju pertumbuhan spesifik menunjukkan bahwa ikan mampu memanfaatkan nutrisi pakan untuk disimpan dalam tubuh dan mengkonversinya menjadi energi. 
Berdasarkan analisis ragam yang telah dilakukan, didapatkan bahwa perlakuan penggunaanfermentasi tepung kulit buah kakao memberikan pengaruh nyata terhadap laju pertumbuhan spesifik ikan mas. Hal ini diduga karena tepung kulit buah kakao yang sudah difermentasi pada perlakuan tersebut meningkatkan kandungan karbohidrat sehingga dapat dimanfaatkan secara optimal sebagai sumber energi. Sesuai dengan pendapat Restiningtyas (2015), karbohidrat yang cukup akan mencegah penggunaan protein untuk energi, sehingga protein yang ada dapat lebih dimanfaatkan untuk pertumbuhan. Rosmawati (2005) menambahkan, pertumbuhan berkorelasi erat dengan sintesis protein, karena pertumbuhan merupakan perubahan jumlah materi tubuh, dan pada ikan sebagian besar penyimpanan materi tersebut dalam bentuk protein, selain itu juga dalam bentuk lemak dan karbohidrat.

\section{Kelulushidupan}

Kelulushidupan ikan mas berpengaruh $(\mathrm{P}<0,05)$ pada perbedaan dosis penambahan fermentasi tepung kulit buah kakao. Setelah dilakukan uji Duncanperlakuan yang tertinggi pada kelulushidupan adalah perlakuan $\mathrm{C}$ dengan dosis penambahan fermentasi kulit buah kakao (T. cacao L.)20\%pada pakan sebesar 96,00 $\pm 4,00 \%$.Nilai kelulushidupan yang terendah pada perlakuan D dengan dosis penambahan fermentasi kulit buah 30\%pada pakan sebesar $84,00 \pm 4,00 \%$. Kelulushidupan ikan uji tidak dipengaruhi oleh pakan secara langsung. Ikan yang mati diduga stres selama pemeliharaan. Menurut, Suprayudi et al. (2012), kelulushidupan ikan mas (C. carpio) tidak dipengaruhi secara langsung oleh pakan saja. Ketersediaan pakan dalam penelitian ini diduga cukup untuk memenuhi kebutuhan ikan dalam mempertahankan diri.Tingginya kelulushidupan menunjukan kualitas dan kuantitas pakan yang diberikan sudah cukup untuk memenuhi kebutuhan pokok dan dapat meningkatkan pertumbuhan

Menurut Fitria (2012), tingkat kelangsungan hidup sangat dipengaruhi oleh kualitas air terutama suhu dan kandungan oksigen. Suhu merupakan salah satu faktor yang memengaruhi pertumbuhan. Suhu dapat memengaruhi aktifitas ikan, seperti pernafasan dan reproduksi. Suhu air sangat berkaitan dengan konsentrasi oksigen terlarut dan laju konsumsi oksigen ikan. Siregar dan Adelina (2009), kelulushidupan dapat dipengaruhi oleh faktor biotik dan abiotik. Faktor biotik terdiri dari umur dan kemampuan ikan dalam menyesuaikan diri dengan lingkungan. Faktor abiotik antara lain ketersediaan makanan dan kualitas media hidup.

\section{Kualitas Air}

Kualitas air merupakan data pendukung dari kegiatan budidaya, hasil pengukuran terhadap beberapa parameter kualitas air diantaranya suhu, pH, oksigen terlarut dan amonia. Berdasarkan kualitas air yang telah diamati selama pemeliharaan ikan mas selama 35 hari, diperoleh hasil suhu yang relatif fluktuatif. Hal tersebut terjadi akibat kondisi lingkungan yang berubah saat hujan. Suhu wadah selama pemeliharaan berkisar $25-30^{\circ} \mathrm{C}$. Suhu tersebut cukup sesuai dengan kondisi ikan mas. Menurut Widiastuti (2009), ikan mas hidup pada kisaran suhu antara $18-30^{\circ} \mathrm{C}$ dan tumbuh terbaik pada kisaran suhu antara $20-28^{\circ} \mathrm{C}$. Perubahan suhu dalam satu hari yang sangat drastis akan mengakibatkan terjadinya stres pada ikan.

Oksigen terlarut yang diukur selama penelitian menunjukan hasil 3,36-4,68 mg/L. Hasil pengamatan oksigen terlarut ini masih sesuai dan layak untuk budidaya ikan mas, hal ini sependapat dengan Widiastuti (2009), oksigen terlarut berkisar antara 3-6 mg/L, kondisi ini masih layak untuk pertumbuhan dan kelulushidupan ikan mas. Nilai $\mathrm{pH}$ yang diperoleh pada saat penelitian yaitu 7 hasil ini masih dalam batas kelayakan dan sesuai dengan pendapat Widiastuti (2009), dimana $\mathrm{pH}$ air untuk budidaya berkisar antara 6-7. Nilai amonia yang diperoleh sebesarmg/L, yang tergolong masih dalam kisaran normal. Menurut Zennoveld et al. (1991), kisaran nilai amonia bagi ikan budidaya berbeda-beda berbeda tergantung jenis ikan, ikan dapat mentolerir daya racun amoniaantara $0,2 \mathrm{mg} / \mathrm{L}$ hingga $2,0 \mathrm{mg} / \mathrm{L}$.

\section{KESIMPULAN DAN SARAN \\ Kesimpulan}

Berdasarkan hasil penelitian dapat disimpulkan bahwa penggunaan fermentasi tepung kulit buah kakao ( $T$. cacao L.) dalam pakan ikan mas (C. carpio) berpengaruh nyata terhadap semua variabel pengukuran dandosis optimum fermentasi tepung kulit buah kakao (T. cacao L.) dalam pakan terhadap efisiensi pemanfaatan pakan dan pertumbuhan ikan mas (C. carpio) berkisar antara 13,8-14,5\%.

Saran

Saran yang dapat diberikan dari penelitian ini adalah

1. Pakan dengan penambahan fermentasi tepung kulit buah kakao (T. cacaoL.) 13,8-14,5\% dapat digunakan dalam budidaya ikan mas (C. carpio) untuk menghasilkan pertumbuhan dengan pemanfaatan pakan yang lebih efisien.

2. Penambahan fermentasi tepung kulit buah kakao (T. cacaoL.) dapat diterapkan pada ikan mas dengan ukuran yang lebih besar atau jenis ikan herbivora lainnya. 


\section{Ucapan Terima Kasih}

Terima kasih penulis ucapkan kepada Bapak Taufik selaku Kepala Balai Benih Ikan Siwarak, Kabupaten Semarang, atas fasilitas sarana dan prasarana yang diberikan dalam penelitian dan semua pihak yang telah membantu mulai dari persiapan hingga jalannya penelitian.

\section{DAFTAR PUSTAKA}

Abidin, Z., M. Junaidi, Paryono, N. Cokrowati, dan S. Yuniarti. 2015.Pertumbuhan dan Konsumsi Pakan Ikan Lele (Clarias sp.) yang Diberi Pakan Berbahan Baku Lokal. Jurnal Depik, 4(1): 33-39.

Ali, M., L. Santoso dan D. Fransiska. 2015. Pengaruh Substitusi Tepung Ikan dengan Tepung Kepala Ikan Teri Terhadap Pertumbuhan Ikan Nila Gift. (Oreochromis sp.). Jurnal Maspari FMIPA Universitas Sriwijaya, $1(35)$.

Anggraeni, N.M., dan N. Abdulgani. 2013. Pengaruh Pemberian Pakan Alami dan Pakan Buatan terhadap Pertumbuhan Ikan Betutu (Oxyeleotris marmorata) pada Skala Laboratorium. Jurnal Sains dan Seni Pomits, 2 (1): 2337-3520.

Dani, N. P., A. Budiharjo dan S. Listyawati. 2005. Komposisi Pakan Buatan untuk Meningkatkan Pertumbuhan dan Kandungan Protein Ikan Tawes (Puntius javanicus Blkr.). BioSmart, 7 (2): 83-90.

Fitria, A.S. 2012. Analisis Kelulushidupan dan Pertumbuhan Benih Ikan Nila Larasati (Oreochromis niloticus) F5 D30-D70 pada Berbagai Salinitas. Fakultas Perikanan dan Ilmu Kelautan, Universitas Diponegoro. Jurnal of Aquaculture Management and Technology, 1(1): 18-34.

Hemre,G.I., T.P.Mommsen., A.Krogdahl. 2002. Carbohydrates in fish nutrition efects on growth, glucose metabolism and hepatic enzymes. Aquaculture Nutrition, 8: 175-194.

Hepher, B. 1988. Nutrition of Food Fisheries. Cambridge University. New York, 388 p.

Hetrampf, J.W and F.P. Pascual. 2000. Handbook on Ingredients for Aquaculture Feeds. Kluwer Acadmic Publishers, London.

Kordi, M.G.H. dan A.B. Tancung. 2007. Pengelolaan Kualitas Air. PT Rineka Cipta, Jakarta, 238 hlm.

Patriono, E., E. Jusadi dan Setiorini. 2009. Pengaruh Pemotongan Sirip terhadap Pertumbuhan Panjang Tubuh Ikan Mas (Cyprinus carpio.). Penelitian Sains Unsri, 09:12-13.

Putri, F.S., H. Zahidah dan H. Kiki. 2012. Pengaruh Pemberian Bakteri Probiotik pada Pelet yang Mengandung Kaliandra (Calliandracalothyrsus) terhadap Pertumbuhan Benih Ikan Nila (Oreochromis niloticus). Jurnal Perikanan dan Kelautan, 3 (4): 283-291.

Restiningtyas, R. 2015. Pemanfaatan Tepung Daun Lamtoro (Laucaena Gluca) yang Telah Difermentasikan dalam Pakan Buatan terhadap Pertumbuhan Benih Ikan Nila Merah (Oreochromis niloticus). Journal of Aquaculture Management and Technology. Universitas Diponegoro. Semarang, 4(2): 26-34.

Rosmawati. 2005. Hidrolisis Pakan Buatan oleh Enzim Pepsin dan Pankreatin untuk Meningkatkan Daya Cerna dan Pertumbuhan Benih Ikan Gurami (Osphronemus gouramy). [Tesis]. Sekolah Pasca Sarjana. Institut Pertanian Bogor, Bogor, $80 \mathrm{hlm}$.

Setiawati, J. E., Tarsim, Y.T. Adipura, dan S. Hudaidah. 2013. Pengaruh Penambahan Probiotik pada Pakan dengan Dosis Berbeda terhadap Pertumbuhan, Kelulushidupan, Efisiensi Pakan dan Retensi Protein Ikan Patin (Pangasius hypophthalmus). E- journal Rekayasa dan Teknologi Budidaya Perairan, 1 (2): 151162.

Siregar, Y.I dan Adelina. 2009. Pengaruh Vitamin C terhadap Peningkatan Hemoglobin (Hb) Darah dan Kelulushidupan Benih Ikan Kerapu Bebek (Cromileptes alvitelis). Jurnal Natur Indonesia, 1: 75-81

[SNI] Standar Nasional Indonesia-7550. 2009. Produksi Pembesaran Ikan Mas di Kolam Air Tenang. Badan Standarisasi Nasional, $12 \mathrm{hlm}$.

Sukardi, S.Helmiati dan Y.Wulandari. 2012. Penggunaan Tepung Kulit Buah Kakao pada Pakan Pengaruhnya Terhadap Pertumbuhan dan Produksi Gurami. Jurnal Perikanan, 14(2): 57-63.

Suprayudi, M.A., D. Harianto, dan D. Jusadi. 2012. Kecernaan Pakan dan Pertumbuhan Ikan Mas (Cyprinus carpio). Jurnal Akuakultur Indonesia,11 (2) : 102-108.

Tacon, A.G. 1987. The Nutrition and Feeding of Farmed Fish and Shrimp-A Traning Mannual. FAO of The United Nations, Brazil, $106-109 \mathrm{p}$

Widiastuti, I. W. 2009. Pertumbuhan dan Kelangsungan Hidup (Survival Rate) Ikan Mas (Cyprinus carpio) yang Dipelihara dalam Wadah Terkontrol dengan Padat Penebaran yang Berbeda. Media Litbang Sulteng, 2 (2): 126-130.

Zonneveld, N.,E.A. Huismandan J. H. Boon. 1991. Prinsip-prinsip Budidaya Ikan. Gramedia. Jakarta, 318 hlm. 